\title{
Developing Moodle in Problem-Based Learning to Improve Student Comprehension on the Concepts of Wave
}

\author{
Lovy Herayanti, Syifaul Gummah, Baiq Azmi Sukroyanti, Sukainil Ahzan \\ Department of Physics Education, IKIP Mataram, Mataram, Indonesia \\ lovyherayanti@ikipmataram.ac.id
}

Gunawan Gunawan

Department of Physics Education, Universitas Mataram, Mataram, Indonesia

\begin{abstract}
E-learning is learning process through electronic media, especially the internet. E-learning enables students to learn or possess science no matter when and where. The purpose of this study was to develop Moodle in problem-based learning in order to improve learners' comprehension of wave concepts. The study was a research and development $(R \& D)$ conducted in four stages, i.e. preliminary study, developing the design, testing Moodle as media for problem-based learning, and dissemination. Subjects of this study were students of physics education program of IKIP Mataram who enrolled wave course. Data on conceptual comprehension were collected through the test, in which experts had validated the test. The result showed improvement in students' comprehension on the concepts of wave. Moreover, students gave a positive response towards the use of Moodle developed as media in problem-based learning.
\end{abstract}

Keywords-Moodle; Problem-Based Learning; Conceptual Comprehension; Concepts of Wave.

\section{INTRODUCTION}

Physics is the study of matter, energy, and its relationships. Physics is a discipline that studies the relationship of various natural phenomena. It is developed based on the results of observation of both experimental and quantitative measurement. Comprehension on the basic of physics enables people to develop technology and science that are used to investigate natural phenomena.

One of the topics in physics is wave. This topic is dealing with abstract concepts that are often difficult to comprehend [1]. For instance, in demonstrating waves that spread through a rope, there is no such wave can be eye-witnessed within the material. In observing waves in the sea, what being observed is the surface of water. There is no way to study wave in the sea without the existence of water. Hakuta et al. [2] stated that students who are taught about wave are expected to be able to explain and predict the nature, characteristics, and patterns of wave that interact with materials. Thus, students are expected to be able to demonstrate their ability in developing and using model, formula, and gain, evaluate as well as communicate the concepts or collected information. Meanwhile, so many misconceptions are demonstrated by students in learning the concept of wave. The abstract of several wave concepts also causes learning difficulties, so that visualisation is needed through the right learning media.

Conceptual comprehension towards course materials is one of the primary objectives of education around the world. One of the observable and measurable learning outcomes is comprehension of concepts. This can be defined as understanding concepts and also its application. Conceptual comprehension also requires learners to be able to create their thinking in the forms of the diagram by reading and understanding concepts in the text [3]. According to Silaban [4], conceptual comprehension is an attempt by learners to record and re-transfer a bulk of information from specific course materials to be used further to solve problems, analyse, interpret of a particular event. Conceptual comprehension is part of knowledge, in which knowledge is the primary dimension of education and cognitive as a dimension of the knowledge. Conceptual comprehension is not merely to understand something simply, but can also be described as the ability to understand, master, apply, classify, generalise, synthesise, and conclude objects [5].

In physics subject, learners are expected to master all concepts, which are later imprinted in learners to help them to understand and overcome questions and problems encountered during the course and real life. Comprehension of fundamental concepts is built by knowing how, when, and why to apply physics becoming very important in physics learning [6]. Learners are considered to have mastered concepts sophisticatedly when they can answer correctly all questions related to the same concepts [7]. Students' conceptual comprehension are developed correctly if they engage well in learning. Better communication between teacher and learners will have better impact on learners regarding conceptual comprehension [8]. Interaction during the learning process should be well designed and prepared.

It is essential for the teacher to generate innovation that can assist learners to comprehend concepts even in limited resources [9]. Moreover, the teacher should give a try for betterment of teaching components. Teaching media is not the only component that determines learning outcomes. The use of the sophisticated instructional model, accurate method, and instructional approach need to get more attention too. 


\section{RESULTS AND DISCUSSION}

Moodle in problem-based learning has developed in this study, which was a learning website, had some characteristics that were highly related to the learning activity. On the website, digital course materials and evaluation for students were attached indicating the transformation of teachercentered learning into student-centered learning. Problembased Moodle in this study contained pictures, animation, and interactive simulation that were dealing with wave as the main topic of the course. Evaluation feature was constructed using quizzes feature that was available on Moodle. In this feature, teacher could set preferred time allocation for students to answer the given test, which encouraged learners to work seriously.

Students demonstrated their ability to comprehend specific concepts in both theories and its application in real life. Before the sessions, students were given pre-test to measure their initial comprehension regarding the topic. Next, students engaged in learning sessions that employed a problem-based learning model. At the end of the course, students were given post-test to inform their learning achievements and improvements about the concepts being learned. Results showed that there was an improvement in learners' comprehension by comparing results of pre-test and post-test. The improvement was measured by comparing mean scores of both tests dealing with four subtopics in wave course, i.e. nature of wave, superposition of wave, sound wave, and wave interference.

Figure 1 shows that the average score in pre-test towards each subtopic. Among the subtopics, learners scored highest when dealing with the nature of wave. It can be understood considering the subtopic emerged in the early session, in which all concepts and equation being learned were yet complicated and more accessible to comprehend by students.

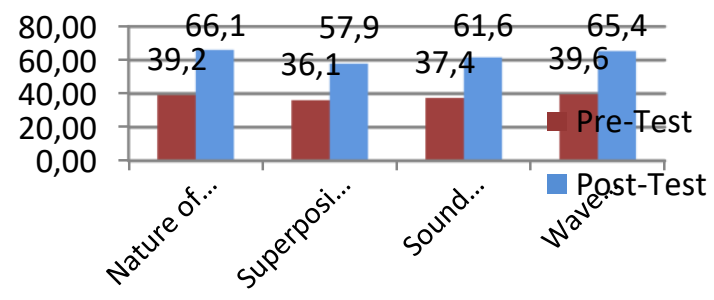

Figure 1. The disparity of mean score of pre-test and post-test in students conceptual comprehension

The lowest percentage is dealing with superposition of wave (57.9), although this issue was not the last subtopic and indicated as the most difficult one. In this concept, many mathematical equations were used, however, only for test items dealing with the application of concepts, students yet able to apply the equations. A similar finding was reported by Wittmann et al. [18] stating students' incompetence in answering same questions in different contexts. Students' failure to understand the meaning of mathematical equations beyond formulation was assumed as the cause of this problem [19]. However, it can be concluded that most students demonstrate improvement regarding conceptual comprehension. This finding supports a study by Herayanti et 
al. [20] that claims typical improvements in learners after engaging Moodle-aid learning in covering some aspects, including cognitive, psychomotor, and effective.

Moodle-based learning in physics course developed in this study was an accessible learning website. It contained materials equipped with exercise and animation display to assist learners in grasping all concepts being taught. The use of animation was proven effective to help learners to cope with abstract concepts sophisticatedly. This finding supports a study by Gunawan et al. [21] that reported how visualisation using computer animation could encourage learners with logical inference and conceptual construction of physics to be better than learners who only experience conventional learning approach.

Based on data analysis of pre-test and post-test, it was found that there was a significant difference regarding conceptual comprehension before and after treatments. This finding proved that the use of problem-based Moodle in this study could improve students' comprehension of concepts being learned. Similar result is also suggested by Hermawanto et al. [5] claiming blended learning, which integrates face to face learning and online learning using Moodle, can improve students' conceptual comprehension and reasoning of physics as well as to train them to be more independent and active in learning.

This study also collected students' feedback through a survey regarding the use of problem-based Moodle as an instructional media, which was given to them after all treatments completed. Students gave positive feedback towards some issues being questioned, such as design of the website, level of convenience and the use of problem-based Moodle as media to study about wave. They also agreed that it helped them to overcome learning difficulty. It was shown by average score recorded by students' in their feedback was of 4.20 , which felt into "good" category. Next, in terms of attractiveness, the survey showed average score of 4.50, which indicated "very good" and regarding level of convenience in using the media, the average score was 4.60 , indicating "very good" response. In the commentary box, most students liked to engage with problem-based Moodle developed as an instructional media in this study inasmuch they found it easier for them to access course materials about the wave. Besides that, the use of animation and interactive simulation gave a pleasant and not tedious learning atmosphere. Students also suggested expanded use of Moodle in other courses. Learning results became the evidence to claim that problem-based Moodle as an instructional media could train learners to be more independent inasmuch they became more active to find materials and do various tasks given. Moreover, it could also facilitate them to access the course anywhere and anytime.

Increased mastery of students' concepts can be seen from the $\mathrm{N}$-gain score. In the concept of the nature of wave, the highest $\mathrm{N}$-gain score is 0.79 , the concept of wave superposition is 0.75 , and the sound wave concept is 0.70 . The three subconcepts of the wave have increased in the high category. While the concept of wave interference is 0.68 , in the medium category. The highest $\mathrm{N}$-gain can be seen in the subject of the nature of waves because this concept is material given at the initial meeting where the concepts and similarities in the material are not too complicated so students can more easily understand it. The results of the research hypothesis test show that there is a significant difference between the initial and final tests. This can be seen from the results of the t-test which gives t-count value of 5.47 (t-table of 2.04). This shows a significant difference in ability in students before and after learning.

Some other studies indicate that online learning, like computer-based media such as Moodle, e-learning, and other virtual media, can improve learning outcomes. Gunawan et al. [15] report that the use of computer-based media in three high schools improves students' conceptual comprehension in a physics course for both male and female, in which improvements occur in all cognitive aspects. Moreover, Gunawan et al. [22] report higher comprehension on concepts performed by learners who engage with interactive multimedia aid compared to those who learn without the same aid. MartinBlas \& Serrano-Fernandez [23] state that online physics learning through Moodle is used to assist teacher and students to have virtual space where they can share knowledge through various activities. Online physics learning can help students to enhance their competence and knowledge. Feedbacks given by students were very good.

\section{CONCLUSION}

The use of Moodle as an instructional media in problembased learning could improve students' conceptual comprehension of the concepts of wave. It can be seen from increased percentages of assessment towards all concepts learned in wave course. Differences in abilities on conceptual comprehension before and after learning differ significantly. Increased mastery of students' concepts is in the medium to high category. In general, all students gave positive feedback towards its design, level of convenience in using it, and the role of this media in learning concepts in wave course. Learning using this media was responded effectively by learners to overcome their learning difficulty. However, their suggestion for the future research was the need to give a preliminary technical briefing about various features offered in the media in order to give the more satisfying result. It is interesting to further investigate the benefit of this media towards other thinking skills, such as critical thinking, creativity, and problem-solving.

\section{ACKNOWLEDGMENTS}

Authors deliver sincere gratitude to the Ministry of Research, technology, and Higher Education of the Republic of Indonesia for awarding the Institutional National Strategic Research scheme in 2017-2018. The team also thank all parties involved during the process and publication of results of this study.

\section{REFERENCES}

[1] R A. Serway and J. W. Jewett, Fisika untuk sains dan teknik. Jakarta: Salemba Teknika, 2009.

[2] K. Hakuta, M. Santos, and Z. Fang, "Challenges and opportunities for language learning in the context of the CCSS and the NGSS", Journal of Adolescent \& Adult Literacy. Vol. 56(6), pp. 451-454, 2013.

[3] J. D. Gobert and J. J., "Clement Effects of student-generated diagrams versus student-generated summaries on conceptual understanding of causal and dynamic knowledge in plate tectonics", Journal of Research in Science Teaching. Vol. 36(1), pp. 39-53, 1999. 
[4] B. Silaban, "Hubungan antara penguasaan konsep fisika dan kreativitas dengan kemampuan memecahkan masalah pada materi pokok listrik statis". Vol. 20(1), pp. 65-75, 2014.

[5] Hermawanto, S. Kusairi, and Wartono, "Pengaruh blended learning terhadap penguasaan konsep dan penalaran fisika peserta didik kelas X", Jurnal Pendidikan Fiska Indonesia. Vol. 9, pp. 67-76, 2013.

[6] C. Lindstrøm and M. D. Sharma, "Link maps and map meetings: scaffolding student learning physical review special topics", Physics Education Research. Vol. 5(1), pp. 1-11, 2009.

[7] A. Tongchai, M. D. Sharma, I. D. Johnston, K. Arayathanitkul, and C. Soankwan, 'Consistency of students' conceptions of wave propagation: findings from a conceptual survey in mechanical waves". Vol. 020101, pp. 1-11, 2011.

[8] S. Sari, "Pengaruh model pembelajaran dan tipe kepribadian terhadap hasil belajar fisika pada siswa SMP swasta di kecamatan Medan Area", Jurnal Tabularasa. Vol. 9(1), pp. 63-80, 2012.

[9] L. Ye, N. S. Wong, and J. W. Y. Ho, "Design, development and evaluation of biochemistry virtual laboratory for blended learning GSTF International", Journal on Education. Vol. 3(2), pp. 40-45, 2016.

[10] S. Psycharis, G. Chalatzoglidis, and M. Kalogiannakis, "Moodle as a learning environment in promoting conceptual understanding for secondary school students", Eurasia Journal of Mathematics, Science \& Technology Education. Vol. 9(1), pp. 11-21, 2013.

[11] N. M. Y. Suranti, G. Gunawan, and H. Sahidu, "Pengaruh model project based learning berbantuan media virtual terhadap penguasaan konsep peserta didik pada materi alat-alat optik", Jurnal Pendidikan Fisika dan Teknologi. Vol. 2(2), pp. 73-79, 2017.

[12] N. Nisrina N, G. Gunawan, and A. Harjono, "pembelajaran kooperatif dengan media virtual untuk peningkatan penguasaan konsep fluida statis siswa", Jurnal Pendidikan Fisika dan Teknologi. 2(2) 66-7, 2016.

[13] G. Gunawan and L. Liliasari, "model virtual laboratory fisika modern untuk meningkatkan disposisi berpikir kritis calon guru", Jurnal Cakrawala Pendidikan. Vol. 31(2), pp. 185-199, 2012.
[14] G. Gunawan, H. Sahidu, A. Harjono, and N. M. Y. Suranti, "The effect of project based learning with virtual media assistance on student's creativity in physics", Cakrawala Pendidikan. Vol. 36(2), pp. 167-179, 2017.

[15] G. Gunawan, A. Harjono, H. Sahidu, and N. Nisrina, "Improving students' creativity using cooperative learning with virtual media on static fluida concept", Journal of Physics: Conference Series. Vol. 1006(1), pp. 012016, 2018.

[16] G. Gunawan, A. Harjono, H. Sahidu, and L. Herayanti, "Virtual laboratory to improve students' problem-solving skills on electricity concept", Jurnal Pendidikan IPA Indonesia. Vol. 6(2): 257-264, 2017.

[17] Sugiyono, "Metode penelitian pendidikan: pendekatan kuantitatif, kualitatif dan R \& D". Bandung: Alfabeta, 2008.

[18] M. C. Wittmann, R. N. Steinberg, and E. F. Redish, "Making sense of how students make sense of mechanical waves", Physics Teacher. Vol. 37(1), pp. 15-21, 1999.

[19] Y. Atriyanti and H. Subiyanto, "Penerapan model pembelajaran poe untuk meningkatkan kompetensi dasar siswa", Chemistry in Education. Vol. 4(1), pp. 61-67v, 2015.

[20] L. Herayanti, H. Habibi, and M. Fuaddunazmi, "Pengembangan media pembelajaran berbasis moodle pada matakuliah fisika dasar", Jurnal Cakrawala Pendidikan. Vol. 36(2), pp. 210-219, 2017.

[21] G. Gunawan, A. Setiawan, and D. H. Widyantoro, "Model virtual laboratory fisika modern untuk meningkatkan keterampilan generik sains calon guru", Jurnal Pendidikan dan Pembelajaran (JPP). Vol. 20(1), pp. 25-32, 2013.

[22] G. Gunawan, A. Harjono, and I. Imran, "Pengaruh multimedia interaktif dan gaya belajar terhadap penguasaan konsep kalor siswa", Jurnal Pendidikan Fisika Indonesia. Vol. 12(2), pp. 118-125, 2016.

[23] T. Martín-Blas T and A. Serrano-Fernández, "The role of new technologies in the learning process: Moodle as a teaching tool", Physics Computers \& Education. Vol. 52(1), pp. 35-44, 2009. 